\title{
仮名文字の複雑性を表す指標としての 周囲長複雑度の妥当性
}

\author{
齋藤 岳人 東京都立大学 樋口 大樹 NTTコミュニケーション科学基礎研究所 \\ 井上 和哉 東京都立大学 小林 哲生 NTTコミュニケーション科学基礎研究所
}

\begin{abstract}
Validity of perimetric complexity index for Japanese Kana character complexity
Taketo Saito (Tokyo Metropolitan University), Hiroki Higuchi (NTT Communication Science Laboratories), Kazuya Inoue (Tokyo Metropolitan University), and Tessei Kobayashi (NTT Communication Science Laboratories)
\end{abstract}

\begin{abstract}
Perimetric complexity, which is a simple metric of character (letter) complexity defined by an image's area and peripheral length, has been widely used, especially in alphabetic orthographies. We examined whether perimetric complexity is also a valid index for Japanese kana characters (hiragana and katakana) by comparing it with subjective complexity. We obtained evaluations of subjective complexities from Japanese and English speakers and calculated the mean of each character for each type of speaker for character-based analyses. The analyses revealed three main findings: (a) Perimetric complexity was highly correlated with subjective complexity $(r \mathrm{~s}>.85)$, and its correlation was higher than that between the subjective complexity and other measures for character complexity (i.e., stroke count). (b) The perimetric complexities were highly correlated across different typefaces, except for significantly different typefaces. (c) Subjective complexity was highly correlated between Japanese and English speakers. These findings suggest that perimetric complexity can also be used as an index for Japanese kana character complexity.
\end{abstract}

Key words: perimetric complexity, subjective complexity, character recognition, hiragana, katakana.

The Japanese Journal of Psychology

J-STAGE Advanced published date: February 10, 2022
われわれがどのように文字を認知しているのか，そ してその認知システムがどのように発達するのか明ら かにすることは, 読み書き研究における重要な課題で ある。文字認知のメカニズムを探るひとつの試みとし て，文字自体の特性に注目する方法がある。文字特性 は文字間の類似性や文字自体の複雑性などからなり， アルファベット語圈では, これらを用いた文字認知の 研究が数多く行われてきた（例えば, Pelli, Burns, Farell, \& Moore-Page, 2006)。一方, 非アルファベット 語圈における文字認知研究では, 刺激として漢字が主 に用いられている。例えば, 中国語話者を対象にして, 視覚的に制限された条件下での認識効率を実際の参加 者のデータと理想的な参加者のモデルとの比較から検

Correspondence concerning this article should be sent to: Taketo Saito, Department of Psychology, Graduate School of Humanities, Tokyo Metropolitan University, Minami-Osawa, Hachioji 192-0397, Japan. (E-mail: s.taketo025@gmail.com)
証したり（Watson \& Ahumada, 2012），文字の物理的 複雑性とその文字を認識するために必要とされるサイ ズとの関連が検討されている（Zhang, Zhang, Xue, Liu, \& Yu, 2007)。これらの結果から, 漢字において文字 の物理的な複雑さが認識効率の低下につながることが 報告されている。しかし，仮名文字についての文字認 知の研究は非常に少なく, 文字についての認知や発達 機序が漢字と同様なのかは十分に解明されていない。 また，文字の種類の少なさや文字を構成する点や線の パターンの単純さから, 仮名文字は漢字よりもアル ファベットに近い特性を持つと考えられ，同じ非アル ファベット語圈の文字であっても, 漢字とは区別して 扱う必要がある。そこで本研究では, 文字特性のひと つである周囲長複雑度の妥当性を仮名文字で検証する ことで，仮名文字の認知や発達機序を明らかにするた めの基盤を提供することを目指す。

本研究では, 以下の三つの理由から, 文字特性のひ 
とつである複雑性に焦点を当てる。一点目は, 複雑性 を利用して文字認知過程を調べることがあるためであ る。例えば, 複雑な文字ほどノイズ下での検出効率が 低下することが報告されている（Pelli et al., 2006）。ま た，低頻度（Tamaoka \& Kiyama, 2013）や見たことの ない文字（Wiley, Wilson, \& Rapp, 2016）を提示した場 合でのみ，複雑な文字ほど認識効率が低下することが 報告されている。これらの結果は，文字を処理する際 に複雑性が文字認知に影響を与える可能性を示唆して いる。したがって, 文字の認知過程を検討する際には, 刺激の形態的な複雑性を考慮する必要がある。

二点目に，文字を刺激とした実験では文字の複雑性 を統制する場合があるためである（Liu, Chen, \& Wang, 2016; 矢後・中山, 2016; Yin \& McBride, 2015)。例えば, 文字列におけるクラウディングの影響を検証した研究 (Grainger, Tydgat, \& Isselé, 2010) や，発達性ディスレ クシア児の視覚的注意スパンを調べた研究（Ziegler, Pech-Georgel, Dufau, \& Grainger, 2010）では，異なる視 覚刺激間の複雑性が統制されている。実験刺激の複雑 性を統制するために, 実験参加者に主観的複雑度を評 定させる場合があるが，実験の主目的の課題に加えて 文字の評定課題を同時に行わせることは，参加者に余 計な負荷を与えることになる。また，二つの課題を一 つの実験で行わせることにより実験結果が交絡する可 能性もある。

三点目は，文字の複雑性が子どもの読み書きの発達 に関与すると考えられるためである。これまでの研究 から，仮名文字の読み書き習得には聴覚的な要因に加 えて視覚的な要因も関与する可能性が示されている。 具体的には，音列から言語を構成する音の単位（日本 語の場合は，モーラ）に音を分割し操作する能力であ る音韻認識能力（天野，1970；高橋，1997）と仮名文 字の読み習得との関連が報告されている。加えて, 仮 名文字の書き習得には図形の模写成績との関連が指摘 されており（猪俣・宇野・酒井・春原, 2016), 形態 を視覚的情報から捉え，それを表すことができる視覚 技能と仮名文字の書き習得との関連が報告されている ことから, 視覚技能の個人差も文字認知の発達に関与 する可能性がある。また，それぞれの文字が有する文 字特性が仮名文字の読み書き習得にどのように関連す るのかも研究されてきた。例えば，国立国語研究所 （1972）の調查では，複雑な形態の文字ほど読みの習 得が遅れる傾向にあることが示されている。このよう に，文字を認知する側の能力と認知される文字の特性 の両方が仮名文字の読み書き習得に影響している。

ただし，これまでの研究で用いられてきた文字の複 雑性の指標には方法論的な問題がある。例えば，国立 国語研究所（1972）の調查では画数を元にした操作的 な方法を用いて文字の複雑性を定義している。「く」 などの 2 直線からなる一画は二要素とみなすなど，解
析者側で恣意的に決めた基準に基づいて複雑度を定め ている。しかし，この指標が観察者の心的辞書内の複 雑性を真に反映しているのか定かではない。また画数 は,アルファベット文字では算出できない指標であり, 文字の複雑性の影響を言語間で比較する際の障壁とも なり得る。

文字の計量的な複雑性を表す指標として，画数以外 で文字認知の研究に広く利用されているものに，周囲 長複雑度（perimetric complexity）がある（例えば, Castet, Descamps, Denis-Noel, \& Cole, 2017; Pelli et al., 2006）。周囲長複雑度とは，文字の形態的特徵から算 出される值であり, 文字の周囲長の二乗を文字のイン ク領域（面積）で割ることによって求められる。

Figure 1 に示したように，文字の周囲長とは黒の太線 で示された文字の周りの長さであり，文字のインク領 域とは白色で示された領域の面積を示している。この 指標は，面積だけではなく，周囲の長さにも依存する ため, 同じ面積であっても周囲長が長いほど周囲長複 雑度は高くなる。したがって，真円とギザギザの付い た円であれば，同じ面積であっても後者のほうが周囲 長複雑度は高くなる。このように, 周囲長複雑度は物 理的な特徵をもとに簡易に算出できるため，異なる言 語の文字でも共通の方法で研究できるという利点があ る。

周囲長複雑度は文字の認知のしやすさと関連するこ とが報告されている。Pelli et al.（2006）は，ノイズ下 でのアルファベット文字の検出効率を調べ, 周囲長複 雑度の值が高い文字ほど検出効率が悪いことを示して いる。また, Lo \& Cheung（2010）は漢字を刺激とし て用い, 周囲長複雑度が高い漢字ほど検出効率が悪く なり，認知が難しくなることを示した。日本語では， ひらがなとカタカナの文字習得に及ぼす影響を調べる 目的で周囲長複雑度が利用されている（樋口・奥村・

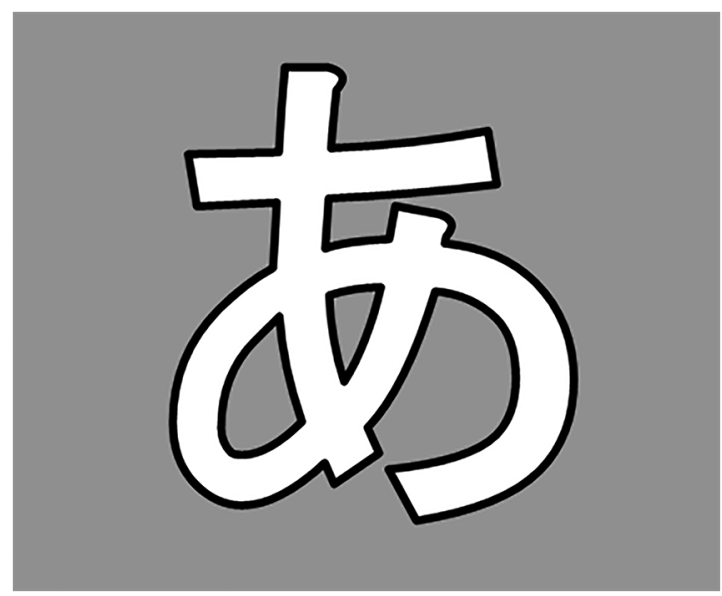

Figure 1. Illustrative example of a method to calculate perimetric complexity. 
小林，2019a，2019b)。画像の面積や周りの長さなと の複数の要素から形態の複雑度を算出する周囲長複雑 度は, 形態の一要素のみを利用するスケルトン長 （Bernard \& Chung, 2011）や文字面積などの計量的な 複雑度（Wang, He, \& Legge, 2014）と比べて, 点や線 の微妙な差異（丸みや尖りなど）も検出可能であるた め, よりヒトの複雑な認知を表した指標であると考え られる。しかし, 周囲長複雑度と文字の主観的複雑度 との直接的な関連は検討されておらず，周囲長複雑度 が観察者の心的辞書内の複雑性を真に反映しているの かという問題は解決されていない。このように，周囲 長複雑度がひらがなとカタカナの心的な主観的複雑度 を十分に反映するかどうか検討する必要がある。

\section{目的}

本研究の目的は, 周囲長複雑度がひらがなとカタカ ナの複雑性を表す指標として妥当かどうか及び指標と しての適用範囲を検証することである。この目的を達 成するために, 以下の 3 点を主に検討する。

第一に, 主観的複雑度と周囲長複雑度の相関係数を 算出することで，周囲長複雑度が仮名文字の複雑性を 表す指標として妥当であるかを検証する。加えて，文 字の物理的特性にもとづく他の指標との比較を通じ て, 周囲長複雑度の相対的な有用性を明らかにする。 具体的には, 日本語漢字の文字認知研究で用いられて きた画数（例えば，Tamaoka \& Kiyama, 2013）と主観 的複雑度との相関係数を比較する。

第二に，周囲長複雑度が書体に依存する指標かどう かを検討する。周囲長複雑度が書体によって大きく変 化する場合，書体ごとに主観的複雑度を評価する必要 があるため，簡便な指標とはいえない。そこで，書体 によって周囲長複雑度が異なるかを確認する。本研究 で主観的複雑度を評定させた MS ゴシック体に加え， 古くから日常的な筆記体として用いられている HGP 行書体，ポスターや広告のロゴなどに用いられている $\mathrm{HG}$ 創英角ポップ体, 印刷物の本文書体として用いら れている明朝体（IPAex と MS の二種類）の周囲長複 雑度を算出し, それらの書体間での周囲長複雑度の相 関係数を比較する。

最後に, 主観的複雑度が形態的要因のみで決まるの か, それとも言語的知識や接触経験 (国立国語研究所, 1972; 垣花, 2015）による影響もあるのかを検討する。 例えば, 日本語話者の場合, 文字の複雑度を評定させ たとしても, 文字音の印象（柔らかい音, 丸い音など） が評定に影響を与えている可能性が否定できない。主 観的複雑度が言語的知識や接触経験によって大きく変 わらないのであれば，本研究で得られた複雑度は，言 語的知識や接触経験の少ない幼児の研究においても利 用可能であり, 文字習得研究においても有用な指標と なる。本研究では，日本語母語話者と英語母語話者間
で主観的複雑度の相関係数を算出することにより，各 文字間での主観的複雑度の相対的関連性が言語的知識 や接触経験に影響されるのかを確認する。加えて, そ の相対的関連性は文字への接触経験によって大きく変 わらないが, 複雑度の評定值自体は接触経験によって 変化する可能性もある。そのため, 相関分析に加えて, 主観的複雑度を日本語話者と英語話者間で比較する。

\section{方法}

\section{実験参加者}

日本語を母語とする 100 名（男性 50 名, 女性 50 名） と英語を母語とする 100 名（男性 50 名, 女性 49 名, どちらでもない 1 名）が実験に参加した。日本語と英 語の母語話者は，日本と英国のそれぞれの現地調査会 社に依頼して集められた。そのため，日本語母語話者 は日本在住，英語母語話者は英国在住であった。年齢 は日本語話者が平均 33.44 歳（標準偏差 4.74）, 英語 話者が平均 31.83 歳 (標準偏差 5.56) であった。また, すべての英語話者は日本語の学習経験がなかった。な お, 本研究はNTTコミュニケーション科学基礎研究 所研究倫理委員会の承認を得て実施された(承認番号： H31-010)。

\section{提示刺激}

ひらがな 71 文字とカタカナ 71 文字を用いた。これ らには，清音など 46 文字（例：「は」，「ひ」，「ふ」) だけではなく，濁音 20 文字（例：「ば」，「び」，「ぶ」) や半濁音 5 文字（例：「ぱ」，「ぴ」，「ぷ」）も含まれて いた（使用した文字の詳細については Appendix を参 照)。文字の書体はすべて MS ゴシック体を利用した。 それぞれの文字は $300 \times 300$ ピクセルの画像として用 意し，パソコンの場合は等倍，スマートフォンの場合 は画面の横幅に合わせて提示した。

\section{手続き}

実験参加者は, Web ブラウザで実験プログラムの URL にアクセスすることで実験に参加した。ひらが なとカタカナの文字のいずれかをディスプレイにひと つずつ提示し，それぞれの文字の複雑度について7 段 階 $(1:$ 全く複雑でない一7：非常に複雑）で評定を行 わせた。すべての文字の提示順はランダマイズした。 参加者が使用する端末は特に指定しなかったため, 使 用する端末の違いによって大きさや明るさなどの提示 条件は異なっていた。ただし，参加者の人数を考慮す ると, これらの提示条件の違いによる実験結果への影 響はランダム要因としてある程度相殺されていたと考 えられる。

試行数の増加を防ぐため, 練習試行は実施しなかっ た。また，文字の視覚的な側面を反映した複雑度を取 
Table 1

Means and standard deviations of subjective complexity rated by Japanese and English speakers

\begin{tabular}{lccc}
\hline \multicolumn{2}{c}{ Character type } & Japanese speakers & English speakers \\
\hline All characters & Mean & 2.26 & 4.15 \\
& $S D$ & 0.41 & 0.94 \\
Hiragana & Mean & 2.44 & 4.53 \\
& $S D$ & 0.43 & 0.95 \\
Katakana & Mean & 2.09 & 3.76 \\
& $S D$ & 0.30 & 0.75 \\
\hline
\end{tabular}

得するために，刺激が仮名文字のみであることを事前 に参加者に教示しなかった。

\section{分 析}

本研究では文字自体の特性を調べることを目的とし たため, 参加者ではなく文字を単位とした分析を行っ た。日本語話者と英語話者ごとに，ひらがなとカタカ ナの文字ごとの評定值を平均し, その文字の主観的複 雑度とした（Appendix）。周囲長複雑度の算出には, 文字向けに提唱されているアルゴリズム（Pelli et al., 2006）を用いた。具体的には, $300 \times 300$ ピクセルの 文字画像を用いて, 文字の周囲の長さと面積をピクセ ル単位で数え, 文字の周囲の長さの二乗を面積で割る ことによって求められた。

\section{結 果}

統計ソフト R version 4.10（R Core Team, 2021）を使 用して分析を行った。まず，話者（日本語話者 vs. 英
Table 2

Correlation coefficients between perimetric and subjective complexities of Japanese and English speakers

\begin{tabular}{lcc}
\hline Character type & Japanese speakers & English speakers \\
\hline All characters & $.87^{* *}$ & $.89^{* *}$ \\
Hiragana & $.85^{* *}$ & $.89^{* *}$ \\
Katakana & $.82^{* *}$ & $.83^{* *}$ \\
\hline$* *<.01$ & &
\end{tabular}

$* * p<.01$

語話者）と表記の種類（ひらがな vs. カタカナ）ごと の主観的複雑度の平均および標準偏差を Table 1 に示 した。また,コルモゴロフ・スミルノフ検定によって，

日本語話者の主観的複雑度（文字全体 $D=0.05$, $p=.79$, ひらがなのみ $D=0.12, p=.24$, カタカナのみ $D=0.06, p=.94$ ） と英語話者の主観的複雑度（文字全 体 $D=0.09, p=.19$, ひがなのみ $D=0.12, p=.23$, 力 夕カナのみ $D=0.08, p=.74 ）$ のそれぞれにおいてデー 夕の正規性が確認された。

\section{周囲長複雑度と主観的複雑度の関連}

周囲長複雑度と主観的複雑度の関連性を明らかにす るため,これらのピアソンの相関係数を算出した（以 降の相関分析では，すべてピアソン積率相関係数を用 いた)。その結果, Figure 2 に示すように, 日本語話 者 $(r=.87, t(140)=20.83, p<.01)$ と英語話者 $(r=.89$, $t(140)=23.24, p<.01)$ の両方で周囲長複雑度と主観 的複雑度の間に高い正の相関が認められた。またひ らがなとカタカナそれぞれで周囲長複雑度と主観的複 雑度の関係性を検討したところ，ひらがなとカタカナ のいずれにおいても高い正の相関が認められ， Table 2
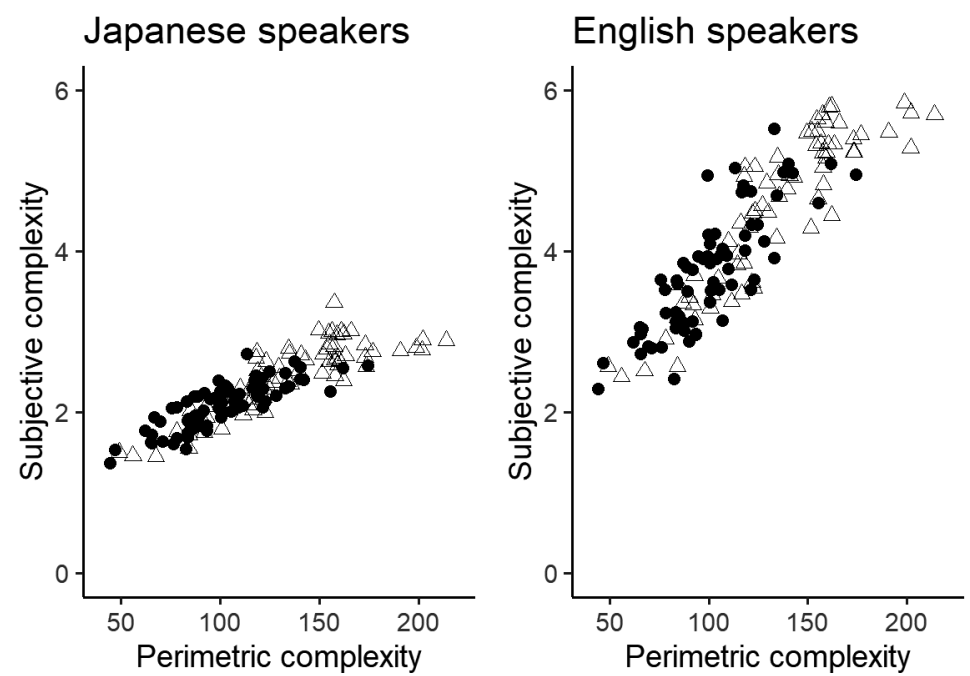

Figure 2. Subjective complexity as a function of perimetric complexity (perimetric ${ }^{2} /$ area) for Japanese and English speakers. Triangles $(\triangle)$ show hiragana characters and black circles $(\mathbf{)})$ show katakana characters. 
Table 3

Correlation coefficients between stroke count and subjective complexity of Japanese and English speakers

\begin{tabular}{lcc}
\hline Character type & Japanese speakers & English speakers \\
\hline All characters & $.74 * *$ & $.79 * *$ \\
Hiragana & $.72 * *$ & $.78^{* *}$ \\
Katakana & $.82 * *$ & $.82 * *$ \\
\hline
\end{tabular}

$* * p<.01$.

に示すように相関係数にも大きな違いは見られなかっ た（日本語話者： $t \mathrm{~s}(69)>11.86, p \mathrm{~s}<.01$; 英語話者 : $\left.t_{\mathrm{s}}(69)>12.25, p_{\mathrm{s}}<.01\right)$ 。これらの結果から, ひらがな とカタカナの文字全体において, 周囲長複雑度が文字 の複雑性を表す指標であることが示された。

\section{周囲長複雑度と画数の妥当性の比較}

周囲長複雑度がその他の計量的指標である画数より も主観的複雑度を表す指標として妥当か検証するた め, 画数と主観的複雑度の関係性を検討した。その結 果, 周囲長複雑度の場合と同様に, 日本語話者 $(r=.74$, $t(140)=13.00, p<.01)$ と英語話者 $(r=.79, t(140)=$ $14.97, p<.01 ）$ の両方で高い正の相関が認められた (Figure 3, Table 3)。また, 周囲長複雑度と同じく，ひ らがなとカタカナそれぞれで画数と主観的複雑度の関 係性を検討したところ，Table 3 に示すように，表記
Table 4

Correlation coefficients of perimetric complexity among each typeface

\begin{tabular}{lccccc}
\hline \multicolumn{1}{c}{ Typeface } & 1 & 2 & 3 & 4 & 5 \\
\hline 1 HGPGyosho & - & $.79^{* *}$ & $.92^{* *}$ & $.91^{* *}$ & $.93^{* *}$ \\
2 HGSoeikakuPop & & - & $.79^{* *}$ & $.87^{* *}$ & $.79^{* *}$ \\
3 IPAexMincho & & & - & $.98^{* *}$ & $.98^{* *}$ \\
4 MSGothic & & & & - & $.96^{* *}$ \\
5 MSMincho & & & & & - \\
\hline
\end{tabular}

$* * p<.01$ (Holm corrected for multiple comparisons).

の種類（ひらがな，カタカナ）にかかわらず高い相関 が認められた（日本語話者： $t_{\mathrm{S}}(69)>8.58, p_{\mathrm{s}}<.01$; 英 語話者: $\left.t_{\mathrm{S}}(69)>10.45, p_{\mathrm{S}}<.01\right)$ 。このように, 画数も 周囲長複雑度と同様にひらがなとカタカナの文字の主 観的複雑度と高い相関を示した。

さらに, 周囲長複雑度と画数のどちらが主観的複雑 度を表す指標として妥当であるかを検討するために， 変数 (主観的複雑度) を共有する二つの相関係数の差 の検定を, psych パッケージ（Revelle, 2021）を使用 して行ったところ，日本語話者と英語話者の両方で主 観的複雑度との相関係数は画数よりも周囲長複雑度の ほうが有意に高い值を示していた（日本語話者： $t=4.90, p<.01$; 英語話者 : $t=4.18, p<.01)$ 。この結果 は, 画数よりも周囲長複雑度のほうがより仮名文字の
Japanese speakers

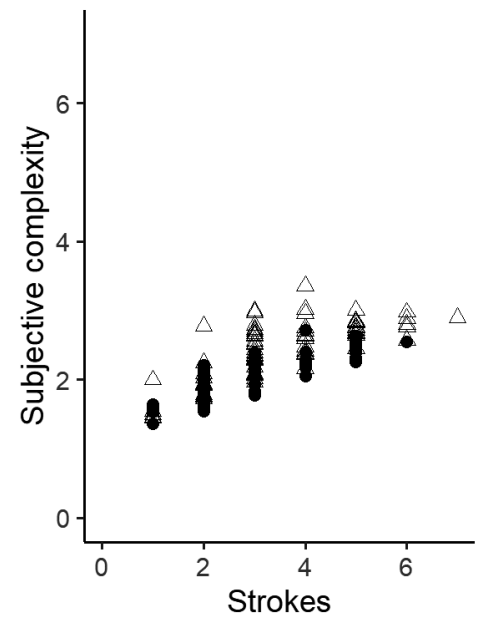

\section{English speakers}

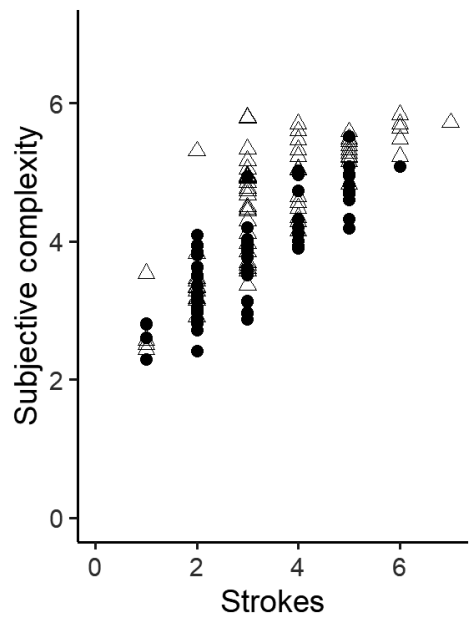

Figure 3. Subjective complexity as a function of strokes for Japanese and English speakers. Triangles $(\triangle)$ show hiragana characters and black circles $(\mathbf{)})$ show katakana characters.

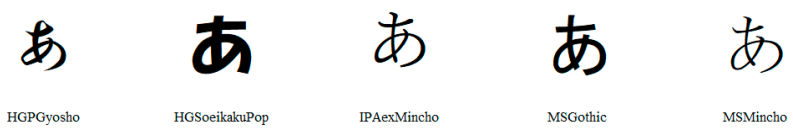

Figure 4. Example of typefaces used for correlational analyses. 
複雑性を表す指標として優れていることを示している。

\section{周囲長複雑度と書体}

周囲長複雑度が書体によって影響を受けるかを検討 するために，書体間での周囲長複雑度の相関係数を算 出した（Table 4; 各書体の例は Figure 4 を参照)。多重 比較に伴う有意水準の調整には Holm 法を用いた。そ の結果, HG 創英角ポップ体を除いた書体間で周囲長 複雑度に.91 以上の高い正の相関が認められた $(t \mathrm{~s}(140)>27.06, p \mathrm{~s}<.01)$ 。それに対して, HG 創英角 ポップ体と他の書体との間で.87 から.79 の高い正の 相関が認められたものの $(t \mathrm{~s}(140)>15.45, p \mathrm{~s}<.01)$, 他の書体間の相関係数と比較して相対的に低い值を示 していた。この結果は, HG 創英角ポップ体の周囲長 複雑度は他の書体の周囲長複雑度とは異なる傾向にあ ることを示している。

\section{言語的知識の影響}

言語的知識が主観的複雑度に及ぼす影響を明らかに するために，日本語話者と英語話者間の関連性を検討 した。まず，日本語話者と英語話者の主観的複雑度の 相関係数を算出した結果, $r=.95$ という非常に高い相 関が認められた $(t(140)=36.15, p<.01)$ 。ただし，

Figure 5 に示したように，話者間で評定值の分布に違 いがあり，英語話者よりも日本語話者のほうが下方に 分布が偏っている傾向が見られた。話者間の主観的複
雑度に対してウェルチの $t$ 検定を行ったところ，日本 語話者のほうが英語話者よりも主観的複雑度が全般的 に低いことが示された $(t(192.98)=-21.98, p<.01)$ 。 したがって，主観的複雑度の文字間の相対的関係性は 日本語話者と英語話者でほぼ同じであるが，英語話者 と比べて日本語話者の主観的複雑度は下方に偏ってお り，分散が小さいことが示された。この結果は，日本 語話者が言語的な知識や経験といった文字の物理的特 性以外の要因の影響を受けて主観的複雑度を評定して いた可能性を示唆している。

\section{考察}

本研究の目的は, ひらがなとカタカナの文字の複雑 性を表す指標として周囲長複雑度を用いることが妥当

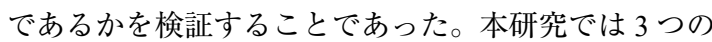
主要な結果を得た。第一に，表記形態にかかわらず周 囲長複雑度が主観的複雑度と高く相関し，その相関係 数は画数と主観的複雑度の值よりも高かった。第二に, 異なる書体間でも周囲長複雑度は高く相関することが 示された。最後に，ひらがなとカタカナ文字に関する 言語的知識を持っている日本語話者は，言語的知識を 持たない英語話者に比べて，主観的複雑度を低く評価 する傾向にあることが示された。

周囲長複雑度と主観的複雑度の間に極めて高い正の 相関が認められたことから, 周囲長複雑度は仮名文字 の複雑性を表す指標であることが示された。この結果
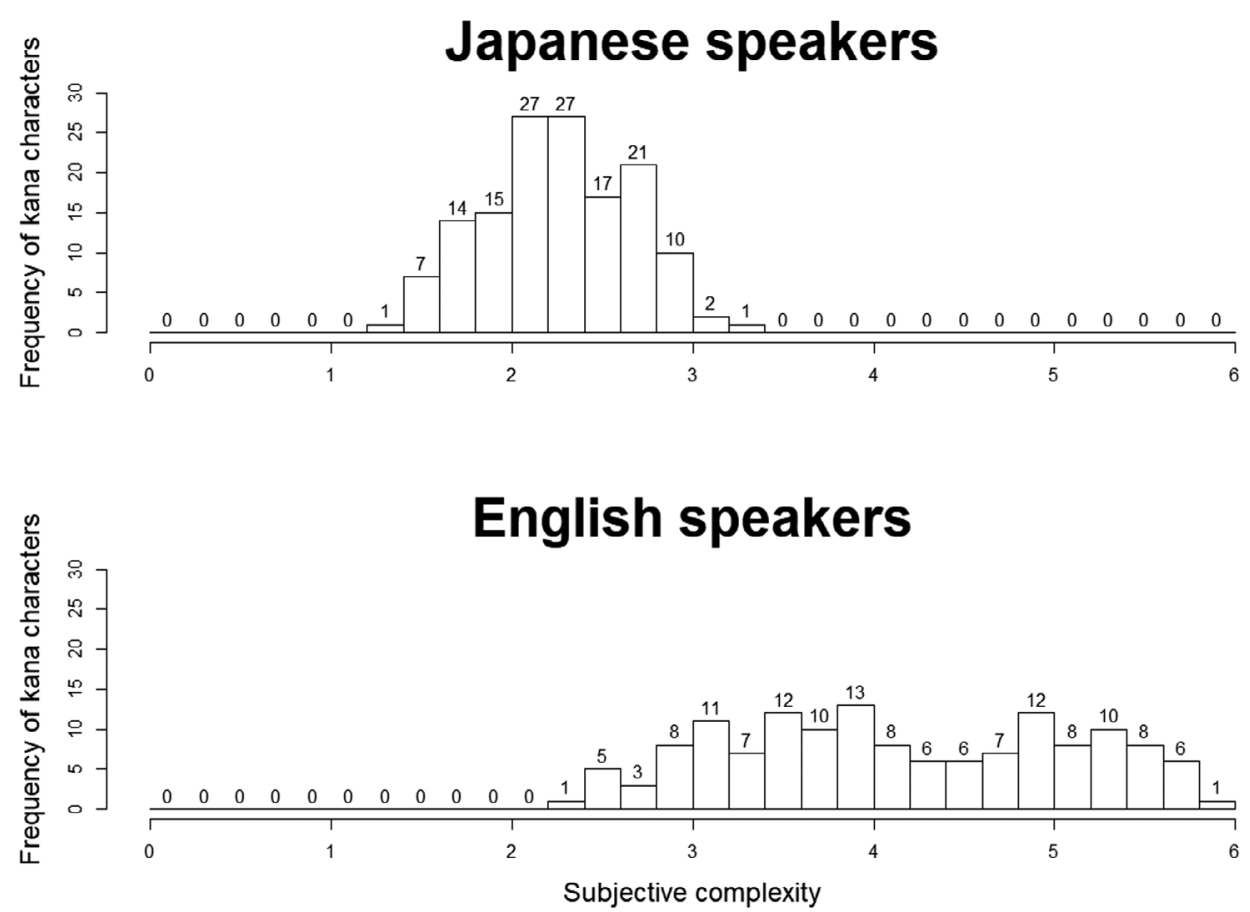

Figure 5. Histograms of subjective complexity for Japanese and English speakers (bin width $=0.20$ ). 
は, ひらがなやカタカナのように類似性の高い文字が 多い場合であっても, 周囲長複雑度は複雑性を表す指 標として利用できることを示唆している。ひらがなや カタカナのみならず, アルファベットや漢字において も, 周囲長複雑度と主観的複雑度の関連が暗黙裏に仮 定されてきたが（樋口・奥村・小林，2019a, 2019b; Lo \& Cheung, 2010; Pelli et al., 2006), 本研究の結果は そのような仮定が妥当であったことを示している。な お，本研究では文字ごとに参加者間平均を算出したう えで, 主観的複雑度と周囲長複雑度の相関係数を算出 した。こうした平均化により，参加者間の回答傾向の 個人差がある程度は相殺されたと考えられる。このた め, 本研究の方法は主観的複雑度と周囲長複雑度の関 連を検討するのに適しており，その結果としてこれら の間に高い相関係数が得られた可能性が考えられる。

また，周囲長複雑度と主観的複雑度の相関係数が画 数と主観的複雑度の相関係数よりも高かったことか ら, 周囲長複雑度は画数よりも文字の複雑性を表す指 標として妥当であることが示された。このことは，ひ らがなとカタカナ文字の形態についての主観的複雑度 が画数のような単純な物理的特性ではなく, 複数の要 素から総合的に判断されている可能性を示唆してい る。先行研究では, 画数では同じ要素間での文字認識 の困難さを表現できないこと（樋口・奥村・小林， 2019a）や画数以外の要因として文字の相称性の影響 を考慮できていないこと（賀集・石原・井上・斎藤・ 前田，1979）が指摘されている。文字の相称性とは, 左右対称の形態を持つ文字のことを示し，相称性のあ る文字ほど「よい形態」とみなされ, 複雑度が低く評 定される傾向がある。ヒトが文字形態の複雑性を評定 する際に様々な物理的特性が利用されているため, 画 数のように，筆を下ろして書き始めてから離すまでに できる点や線を合計するだけの指標では，文字認知に 必要な視覚的情報を十分に表現できなかった可能性が ある。

周囲長複雑度は書体間の相関が高く, 書体に依存し ない指標であることも示された。このことは, 本研究 で用いた MS ゴシック体以外の書体においても, 周囲 長複雑度が文字の複雑性を表す指標として利用できる ことを示唆している。ただし, $\mathrm{HG}$ 創英角ポップ体の 周囲長複雑度は他の書体の周囲長複雑度との相関がや や低かった。ひとつの理由として，ポスターや広告な どに用いられる $\mathrm{HG}$ 創英角ポップ体は, 他の書体に比 べてフォントの丸みが強調されているため, 他の書体 の周囲長複雑度との相関係数が $\mathrm{HG}$ 創英角ポップ体以 外の書体間の相関係数と比べて低い值を示した可能性 が考えられる。このことから, 本研究で得られた MS ゴシック体における周囲長複雑度と主観的複雑度の関 係を，文字の形態が大きく異なる書体に適用すること には注意が必要である。
日本語話者と英語話者の主観的複雑度の相関は極め て高く, 周囲長複雑度と主観的複雑度の相関は話者の 種類にかかわらず同程度であった。この結果は, 言語 的知識や経験の有無にかかわらず，ひらがなとカタカ ナの形態自体にもとづいて主観的な複雑性が規定され ていることを示唆している。一方，文字に関する言語 的知識を持っている日本語話者は，言語的知識を持た ない英語話者に比べて主観的複雑度の得点の分布が下 方に偏っており, 分散も小さかった。この結果から, 日本語話者は文字の物理的特性以外の要因も利用し, 複雑度を評定していた可能性が示唆される。賀集他 （1979）は，よく知っている漢字ほど主観的複雑度が 低下することを報告している。このことから，ひらが なやカタカナへの接触頻度が高く, 熟知感の高い日本 語話者のほうが英語話者よりも全般的に複雑度を低く 評価した可能性が考えられる。また，日本語話者はひ らがなとカタカナに加えて漢字を併用していることも 主観的複雑度が低かった一因であると考えられる。日 本語話者は，形態的により複雑な文字体系である漢字 が日本語に存在することを知っているため, 主観的複 雑度を全般的に低く評価したと考えられる。本研究で は，ひらがなとカタカナのみを対象としたが，今後は 漢字も含めより広範な文字の複雑性に関する検討を行 う必要がある。

言語的知識の有無は主観的複雑度の相対的な関倸性 にはほとんど影響しないが, 主観的複雑度の評定值自 体には影響しうる可能性が示唆された。したがって, 読み習得前の未就学児を対象とし, 複雑度の評定值自 体が影響を及ぼしうる研究に本研究の結果を適用する 際には注意が必要である。こうした目的で複雑度を利 用するには，異なる発達段階の子どもを対象とした主 観的複雑度に関する評定データを別途取得する必要が あるかもしれない。

\section{利益相反}

なお，本論文に関して，開示すべき利益相反関連事 項はない。

\section{引用文献}

天野 清 (1970)。語の音韻構造と分析行為の形成とか な文字の読み学習 教育心理学研究, 18, 76-89. http://doi.org/10.5926/jjep1953.18.2_76

Bernard, J-B., \& Chung, S. T. L. (2011). The dependence of crowding on flanker complexity and target-flanker similarity. Journal of Vision, 11(8), 1. https://doi. org/10.1167/11.8.1

Castet, E., Descamps, M., Denis-Noel, A., \& Cole, P. (2017). Letter and symbol identification: No evidence for letter specific crowding mechanisms. Journal of Vision, 17(11), 2. https://doi.org/10.1167/17.11.2 
Grainger, J., Tydgat, I., \& Isselé, J. (2010). Crowding affects letters and symbols differently. Journal of Experimental of Psychology. Human Perception and Performance, 36, 673-688. https://doi.org/10.1037/a0016888

樋口 大樹 - 奥村 優子 - 小林 哲生 (2019a). 幼児の ひらがな読み書き習得に及ぼす文字特性の影響 音声言語医学, 60, 113-120. https://doi.org/10.5112/ jjlp.60.113

愑口 大樹 - 奥村 優子 - 小林 哲生 (2019b). 幼児の カタカナ読み書き習得に関与する文字特性の検討 音声言語医学, 60, 230-237. https://doi.org/10.5112/ jjlp. 60.230

猪俣 明恵 - 宇野 彰 - 酒井 厚 - 春原 則子 (2016). 年長児のひらがなの読み書き習得に関わる認知能 力と家庭での読み書き関連活動 音声言語医学, 57, 208-216. http://doi.org/10.5112/jjlp.57.208

垣花 真一郎 (2015). 幼児の仮名文字の読み習得に影 響する文字側の諸要因 発達心理学研究, 26, 237 -247. http://doi.org/10.11201/jjdp.26.237

賀集 寛 - 石原 岩太郎 - 井上 道雄 - 斎藤 洋典 - 前 田 泰宏(1979). 漢字の視覚的複雑性 人文論究, 29, 103-121.

国立国語研究所 (1972). 幼览の読み書き能力 東京 書籍

Liu, D., Chen, X., \& Wang, Y. (2016). The impact of visual-spatial attention on reading and spelling in Chinese children. Reading and Writing, 29, 1435-1447. https:// doi.org/10.1007/s11145-016-9644-x

Lo, O. T., \& Cheung, S. H. (2010). Chinese character recognition is limited by overall complexity, not by number of strokes or stroke patterns. Journal of Vison, 10(7), 977. https://doi.org/10.1167/10.7.977

Pelli, D. G., Burns, C. W., Farell, B., \& Moore-Page, D. C. (2006). Feature detection and letter identification. $\mathrm{Vi}$ sion Research, 46, 4646-4674. https://doi.org/10.1016/ j.visres.2006.04.023

R Core Team (2021). R: A language and environment for statistical computing. R Foundation for Statistical Computing, Vienna, Austria. Retrieved from https:// www.R-project.org/

Revelle, W. (2021). psych: Procedures for Psychological, Psychometric, and Personality Research. Northwestern
University, Evanston, Illinois. R package version 2.1.3. Retrieved from https://CRAN.R-project.org/ package $=$ psych

高橋 登 (1997). 幼児のことば遊びの発達一一「り とり」を可能にする条件の分析——発達心理学 研究, 8, 42-52. https://doi.org/10.11201/jjdp.8.42

Tamaoka, K., \& Kiyama, S. (2013). The effects of visual complexity for Japanese kanji processing with high and low frequencies. Reading and Writing: An Interdisciplinary Journal, 26, 205-223.

Wang, H., He, X., \& Legge, G. E. (2014). Effect of pattern complexity on the visual span for Chinese and alphabet characters. Journal of Vision, 14(8), 6. https://doi. org/10.1167/14.8.6

Watson, A. B., \& Ahumada, A. J. (2012). Modeling acuity for optotypes varying in complexity. Journal of Vision, 12(10), 19. https://doi.org/10.1167/12.10.19

Wiley, R. W., Wilson, C., \& Rapp, B. (2016). The effects of alphabet and expertise on letter perception. Journal of Experimental of Psychology: Human Perception and Performance, 42, 1186-1203.

矢後 妃奈子 - 中山 実 (2016). 漢字画像の特徴操作 とRSVP 課題における注意の瞬きとの関係 映像 情報メディア学会誌, 70, J166-J169. http://doi. org/10.3169/itej.70.J166

Yin, L., \& McBride, C. (2015). Chinese kindergartners learn to read characters analytically. Psychological Science, 26, 424-432. https://doi.org/10.1177/ 0956797614567203

Zhang, J-Y., Zhang, T., Xue, F., Liu, L., \& Yu, C. (2007). Legibility variations of Chinese characters and implications for visual acuity measurement in Chinese reading population. Investigative Ophthalmology \& Visual Science, 48, 2383-2390. https://doi.org/10.1167/iovs. 06-1195

Ziegler, J. C., Pech-Georgel, C., Dufau, S., \& Grainger, J. (2010). Rapid processing of letters, digits and symbols: What purely visual-attentional deficit in developmental dyslexia? Development Science, 13, F8-F14. https://doi.org/10.1111/j.1467-7687.2010.00983.x

- 2021. 3.2 受稿, 2021.9.12 受理 
Appendix

Means $(M)$ and standard deviations $(S D)$ of subjective complexity for each character and its corresponding perimetric complexity (MSGothic)

\begin{tabular}{|c|c|c|c|c|c|}
\hline & \multicolumn{2}{|c|}{ Japanese speakers } & \multicolumn{2}{|c|}{ English speakers } & \multirow{2}{*}{$\begin{array}{c}\text { Perimetric complexity } \\
\text { MSGothic }\end{array}$} \\
\hline & $M$ & $S D$ & $M$ & $S D$ & \\
\hline あ & 3.00 & 1.88 & 5.79 & 1.17 & 160.92 \\
\hline$w$ & 1.72 & 1.02 & 3.18 & 1.64 & 84.12 \\
\hline う & 1.92 & 1.15 & 3.35 & 1.78 & 86.98 \\
\hline え & 2.63 & 1.63 & 5.05 & 1.31 & 123.23 \\
\hline お & 2.70 & 1.65 & 5.33 & 1.32 & 163.31 \\
\hline か & 2.35 & 1.37 & 4.68 & 1.53 & 135.48 \\
\hline が & 2.84 & 1.77 & 5.39 & 1.47 & 173.11 \\
\hline き & 2.59 & 1.55 & 5.23 & 1.50 & 159.29 \\
\hline ぎ & 2.80 & 1.68 & 5.84 & 1.09 & 198.86 \\
\hline$<$ & 1.46 & 0.90 & 2.44 & 1.63 & 55.99 \\
\hline ぐ & 2.07 & 1.16 & 3.70 & 1.67 & 92.85 \\
\hline け & 2.18 & 1.25 & 3.61 & 1.70 & 121.82 \\
\hline げ & 2.45 & 1.41 & 4.83 & 1.36 & 157.89 \\
\hline$こ$ & 1.76 & 1.16 & 2.91 & 1.77 & 78.19 \\
\hline ご & 2.16 & 1.21 & 4.35 & 1.58 & 116.04 \\
\hline さ & 2.34 & 1.35 & 4.50 & 1.43 & 123.45 \\
\hline ざ & 2.64 & 1.53 & 5.33 & 1.23 & 160.28 \\
\hline L & 1.45 & 0.95 & 2.51 & 1.68 & 67.63 \\
\hline じ & 2.08 & 1.22 & 3.66 & 1.71 & 104.69 \\
\hline す & 2.51 & 1.50 & 4.74 & 1.37 & 118.80 \\
\hline ず & 2.72 & 1.58 & 5.49 & 1.30 & 151.91 \\
\hline せ & 2.52 & 1.44 & 4.77 & 1.39 & 139.57 \\
\hline ぜ & 2.75 & 1.62 & 5.45 & 1.35 & 176.89 \\
\hline そ & 2.67 & 1.68 & 4.93 & 1.39 & 117.99 \\
\hline ぞ & 2.85 & 1.70 & 5.49 & 1.31 & 154.97 \\
\hline た & 2.38 & 1.38 & 4.16 & 1.56 & 134.17 \\
\hline だ & 2.57 & 1.52 & 5.23 & 1.38 & 173.56 \\
\hline$ち$ & 2.29 & 1.27 & 4.47 & 1.37 & 122.22 \\
\hline ぢ & 2.67 & 1.58 & 5.16 & 1.37 & 159.23 \\
\hline つ & 1.55 & 1.10 & 2.57 & 1.66 & 84.19 \\
\hline づ & 2.09 & 1.26 & 3.85 & 1.67 & 117.85 \\
\hline$\tau$ & 1.75 & 1.18 & 3.33 & 1.65 & 92.09 \\
\hline で & 2.42 & 1.32 & 4.48 & 1.49 & 129.91 \\
\hline と & 1.94 & 1.16 & 3.43 & 1.60 & 90.28 \\
\hline ど & 2.37 & 1.37 & 4.57 & 1.41 & 126.96 \\
\hline な & 2.82 & 1.69 & 5.22 & 1.48 & 157.38 \\
\hline に & 1.97 & 1.14 & 3.37 & 1.74 & 111.65 \\
\hline ぬ & 2.97 & 1.85 & 5.80 & 1.33 & 162.16 \\
\hline ね & 2.96 & 1.80 & 5.60 & 1.27 & 158.98 \\
\hline の & 2.00 & 1.20 & 3.54 & 1.74 & 122.77 \\
\hline は & 2.63 & 1.60 & 4.65 & 1.45 & 155.21 \\
\hline ば & 2.76 & 1.65 & 5.48 & 1.42 & 190.89 \\
\hline ぱ & 2.77 & 1.70 & 5.28 & 1.39 & 201.92 \\
\hline ひ & 2.03 & 1.21 & 3.47 & 1.64 & 116.70 \\
\hline
\end{tabular}




\begin{tabular}{|c|c|c|c|c|c|}
\hline & \multicolumn{2}{|c|}{ Japanese speakers } & \multicolumn{2}{|c|}{ English speakers } & \multirow{2}{*}{$\frac{\text { Perimetric complexity }}{\text { MSGothic }}$} \\
\hline & $M$ & $S D$ & $M$ & $S D$ & \\
\hline び & 2.48 & 1.44 & 4.29 & 1.53 & 151.49 \\
\hline ぴ & 2.39 & 1.36 & 4.44 & 1.52 & 162.20 \\
\hline ふ & 2.75 & 1.62 & 5.05 & 1.25 & 118.42 \\
\hline ぶ & 2.98 & 1.72 & 5.64 & 1.37 & 154.67 \\
\hline ぷ & 3.01 & 1.89 & 5.59 & 1.30 & 165.94 \\
\hline$へ$ & 1.50 & 1.00 & 2.57 & 1.75 & 49.16 \\
\hline べ & 2.02 & 1.16 & 3.58 & 1.74 & 85.10 \\
\hline ペ & 1.93 & 1.17 & 3.15 & 1.58 & 93.06 \\
\hline ほ & 2.68 & 1.59 & 5.23 & 1.27 & 173.06 \\
\hline ほ & 2.90 & 1.75 & 5.72 & 1.44 & 202.12 \\
\hline ぽ & 2.89 & 1.69 & 5.70 & 1.25 & 214.05 \\
\hline ま & 2.65 & 1.61 & 5.04 & 1.36 & 157.74 \\
\hline み & 2.65 & 1.65 & 4.92 & 1.35 & 143.09 \\
\hline む & 3.02 & 1.80 & 5.47 & 1.27 & 149.56 \\
\hline め & 2.78 & 1.78 & 5.31 & 1.49 & 154.04 \\
\hline$も$ & 2.44 & 1.42 & 4.30 & 1.50 & 120.71 \\
\hline や & 2.56 & 1.51 & 4.85 & 1.51 & 129.44 \\
\hline$ゆ$ & 3.00 & 1.84 & 5.34 & 1.33 & 156.52 \\
\hline$よ$ & 2.30 & 1.36 & 4.12 & 1.46 & 110.05 \\
\hline 5 & 2.28 & 1.29 & 3.97 & 1.59 & 114.74 \\
\hline$\eta$ & 1.79 & 1.03 & 3.29 & 1.62 & 100.87 \\
\hline る & 2.71 & 1.67 & 4.94 & 1.43 & 140.76 \\
\hline れ & 2.73 & 1.69 & 4.95 & 1.37 & 135.02 \\
\hline ろ & 2.09 & 1.30 & 3.83 & 1.63 & 114.40 \\
\hline わ & 2.79 & 1.69 & 5.17 & 1.33 & 134.64 \\
\hline を & 3.36 & 1.87 & 5.70 & 1.27 & 157.50 \\
\hline ん & 2.25 & 1.4 & 3.46 & 1.51 & 101.81 \\
\hline ア & 2.16 & 1.29 & 3.94 & 1.68 & 94.74 \\
\hline イ & 1.63 & 0.97 & 3.05 & 1.71 & 65.15 \\
\hline ウ & 2.02 & 1.08 & 3.77 & 1.65 & 91.71 \\
\hline I & 1.83 & 1.10 & 2.88 & 1.84 & 90.05 \\
\hline オ & 2.26 & 1.25 & 4.21 & 1.56 & 103.21 \\
\hline 力 & 2.06 & 1.15 & 3.95 & 1.53 & 109.25 \\
\hline ガ & 2.40 & 1.39 & 4.97 & 1.35 & 142.29 \\
\hline キ & 2.06 & 1.27 & 3.52 & 1.81 & 121.42 \\
\hline ギ & 2.26 & 1.32 & 4.60 & 1.48 & 155.39 \\
\hline ク & 1.89 & 1.07 & 3.63 & 1.58 & 83.62 \\
\hline グ & 2.30 & 1.31 & 4.73 & 1.49 & 116.44 \\
\hline ケ & 2.19 & 1.25 & 3.85 & 1.61 & 87.01 \\
\hline ゲ & 2.42 & 1.39 & 4.74 & 1.40 & 121.25 \\
\hline コ & 1.69 & 1.02 & 3.04 & 1.77 & 83.45 \\
\hline ゴ & 2.21 & 1.21 & 4.01 & 1.60 & 118.32 \\
\hline サ & 2.13 & 1.19 & 4.03 & 1.49 & 107.08 \\
\hline ザ & 2.41 & 1.44 & 5.09 & 1.40 & 140.35 \\
\hline シ & 2.13 & 1.32 & 3.13 & 1.73 & 83.30 \\
\hline ジ & 2.45 & 1.41 & 4.19 & 1.67 & 118.21 \\
\hline ス & 1.92 & 1.16 & 3.59 & 1.68 & 84.03 \\
\hline ズ & 2.39 & 1.42 & 4.82 & 1.29 & 117.28 \\
\hline セ & 2.22 & 1.27 & 3.99 & 1.59 & 107.68 \\
\hline ゼ & 2.56 & 1.50 & 4.98 & 1.35 & 140.60 \\
\hline ソ & 1.88 & 1.15 & 2.82 & 1.74 & 69.54 \\
\hline
\end{tabular}




\begin{tabular}{|c|c|c|c|c|c|}
\hline & \multicolumn{2}{|c|}{ Japanese speakers } & \multicolumn{2}{|c|}{ English speakers } & \multirow{2}{*}{$\frac{\text { Perimetric complexity }}{\text { MSGothic }}$} \\
\hline & $M$ & $S D$ & $M$ & $S D$ & \\
\hline ゾ & 2.26 & 1.28 & 4.20 & 1.44 & 99.88 \\
\hline 夕 & 2.39 & 1.38 & 4.94 & 1.26 & 99.27 \\
\hline ダ & 2.48 & 1.49 & 5.52 & 1.34 & 132.97 \\
\hline チ & 2.30 & 1.31 & 3.90 & 1.60 & 103.89 \\
\hline ヂ & 2.63 & 1.52 & 4.98 & 1.22 & 137.50 \\
\hline ツ & 2.24 & 1.30 & 3.13 & 1.66 & 91.96 \\
\hline ヅ & 2.51 & 1.51 & 4.33 & 1.54 & 124.74 \\
\hline テ & 2.12 & 1.18 & 3.51 & 1.70 & 100.97 \\
\hline デ & 2.32 & 1.29 & 4.69 & 1.45 & 134.39 \\
\hline ト & 1.77 & 1.11 & 2.87 & 1.73 & 62.06 \\
\hline ド & 2.17 & 1.24 & 3.90 & 1.53 & 97.09 \\
\hline ナ & 1.74 & 1.11 & 3.24 & 1.79 & 83.44 \\
\hline ニ & 1.54 & 0.97 & 2.41 & 1.77 & 82.60 \\
\hline 又 & 2.21 & 1.20 & 4.09 & 1.51 & 100.44 \\
\hline ネ & 2.72 & 1.57 & 5.03 & 1.27 & 113.32 \\
\hline ノ & 1.37 & 1.02 & 2.29 & 1.75 & 44.30 \\
\hline 八 & 1.61 & 0.98 & 2.72 & 1.74 & 65.47 \\
\hline バ & 2.05 & 1.14 & 3.94 & 1.70 & 99.25 \\
\hline パ & 2.08 & 1.28 & 3.58 & 1.73 & 111.37 \\
\hline 匕 & 1.96 & 1.08 & 3.01 & 1.78 & 87.37 \\
\hline ビ & 2.29 & 1.38 & 4.33 & 1.65 & 121.51 \\
\hline ピ & 2.30 & 1.28 & 3.91 & 1.58 & 132.99 \\
\hline フ & 1.60 & 1.05 & 2.81 & 1.81 & 76.26 \\
\hline ブ & 2.03 & 1.24 & 3.98 & 1.73 & 106.72 \\
\hline プ & 2.13 & 1.25 & 3.64 & 1.57 & 122.88 \\
\hline$へ$ & 1.53 & 0.99 & 2.61 & 1.73 & 46.79 \\
\hline ベ & 2.06 & 1.32 & 3.52 & 1.62 & 77.90 \\
\hline ペ & 1.96 & 1.16 & 3.50 & 1.80 & 89.34 \\
\hline ホ & 2.21 & 1.26 & 4.12 & 1.56 & 128.12 \\
\hline ボ & 2.55 & 1.49 & 5.09 & 1.39 & 161.71 \\
\hline ポ & 2.58 & 1.49 & 4.95 & 1.34 & 174.34 \\
\hline マ & 2.05 & 1.17 & 3.64 & 1.59 & 75.68 \\
\hline$ミ$ & 1.83 & 1.07 & 2.96 & 1.80 & 93.29 \\
\hline 厶 & 2.20 & 1.27 & 3.80 & 1.55 & 88.71 \\
\hline x & 1.72 & 0.93 & 2.97 & 1.76 & 65.56 \\
\hline モ & 2.23 & 1.29 & 3.78 & 1.65 & 109.78 \\
\hline$ヤ$ & 2.02 & 1.13 & 3.85 & 1.65 & 100.45 \\
\hline 工 & 1.85 & 1.06 & 3.19 & 1.72 & 84.99 \\
\hline$\exists$ & 2.14 & 1.22 & 3.14 & 1.65 & 106.97 \\
\hline ラ & 2.01 & 1.18 & 3.52 & 1.76 & 105.33 \\
\hline リ & 1.68 & 1.03 & 3.23 & 1.81 & 78.25 \\
\hline ル & 1.94 & 1.08 & 3.37 & 1.75 & 100.53 \\
\hline レ & 1.64 & 1.11 & 2.80 & 1.87 & 71.14 \\
\hline 口 & 1.77 & 1.14 & 2.97 & 1.80 & 93.30 \\
\hline ワ & 1.79 & 1.09 & 3.13 & 1.59 & 86.23 \\
\hline 7 & 2.33 & 1.33 & 3.61 & 1.74 & 102.47 \\
\hline ン & 1.94 & 1.19 & 3.03 & 1.71 & 66.54 \\
\hline
\end{tabular}

